\title{
PENGARUH VALUE CONGRUENCE DAN CORE SELF-EVALUATIONS TERHADAP JOB ENGAGEMENT DAN DAMPAKNYA PADA ORGANIZATIONAL CITIZENSHIP BEHAVIOR
}

\author{
Ignatius Soni Kurniawan \\ Fakultas Ekonomi Universitas Sarjanawiyata Tamansiswa, Jl. Kusumanegara No. 121 \\ Yogyakarta 55165, Indonesia \\ Email: soni_kurniawan@ustjogja.ac.id
}

\begin{abstract}
ABSTRAK
Usaha Kecil Menengah (UKM) Kerajinan di Kasongan Bantul Yogyakarta memiliki reputasi sebagai UKM dengan pemasaran yang mampu menembus pasar luar negeri. Bagaimana organizational citizenship behavior (OCB) dan job engagement karyawan dibentuk sehingga dapat mendorong kinerja UKM tersebut, merupakan hal yang dikaji dalam penelitian ini. Menggunakan 107 karyawan UKM Kerajinan di Kasongan Bantul Yogyakarta, penelitian berhasil membuktikan bahwa value conggruence berpengaruh langsung maupun tidak langsung melalui job engagement terhadap OCB. Sebaliknya penelitian tidak membuktikan pengaruh core self-evaluations terhadap OCB baik langsung maupun tidak langsung melalui job engagement. Kata kunci: value congruence, core self-evaluations, job engagement, organizationa citizenship behavior.
\end{abstract}

\begin{abstract}
SMEs in Kasongan Bantul have a good reputation as SMEs that are able to penetrate in foreign markets. How OCB and Employee JE formed so that it can pull SMEs performance is the main issue being discussed in this research. Asking for 107 employees of SMEs in Kasongan craft industry bantul to fill in the questionnaire, this research can prove that value congruence directly or indirectly affects employee JE on $O C B$. Unfortunately, this research is unable to prove the effect of CSE on OCB direcly or indirecly.

Key words: value congruence, core self-evaluations, job engagement, organizational citizenship behavior.

\section{PENDAHULUAN}

Manusia secara individu maupun kelompok mempunyai peran mendasar dalam pencapaian visi perusahaan. Perusahaan seringkali telah memiliki sumber daya manusia terampil, namun tidak berdampak

besar dalam kontribusinya mencapai visi. Karyawan yang hanya memenuhi tugas pokoknya saja, seringkali nampak sebagai karyawan baik, namun sebenarnya mereka menyimpan potensi menganggur. Menggunakan karyawan UKM
\end{abstract}


pengrajin di daerah Kasongan, Kabupaten Bantul Daerah Istimewa Yogyakarta, penelitian ini menganalisis kontribusi pekerja terhadap perusahaannya. Fenomena kinerja karyawan yang berkontribusi pada pencapaian UKM dengan bidang usaha kerajinan dan hasil karya seni yang memenuhi ekspektasi pasar dalam dan luar negeri, menarik untuk dipahami penyebabnya. Menggunakan sudut pandang konsep organizational citizenship behavior (OCB) yang menekankan pentingnya mengusahakan pekerja untuk berkontribusi bagi perusahaan, perilaku ekstra pekerja secara bersama-sama dapat meningkatkan efektifitas organisasi, yang dalam hal ini dapat diterapkan juga pada UKM yang secara organisasi masih belum terorganisasi dengan jelas. Semangat wirausaha pada UKM dapat dikaitkan dengan OCB yang berkontribusi membuat UKM menjadi berkembang serta menjadi senjata penyintas dari persaingan.

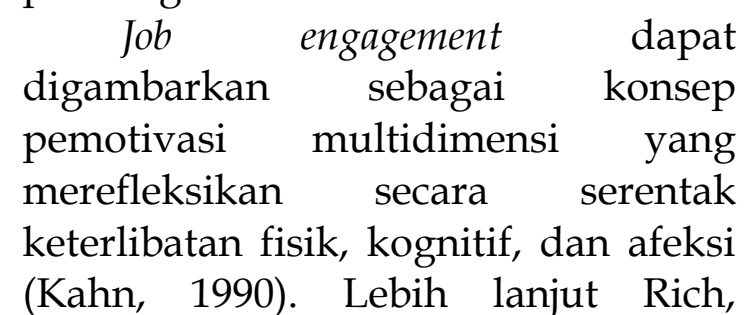
Lepine, \& Crawford (2010) mengadopsi pendapat Kahn (1990) bahwa job engagement memiliki anteseden nilai keselarasan (value congruence), dukungan organisasi yang dirasakan (perceived organizational support), evaluasi inti diri (core self-evaluations); dan memperluasnya dengan mengujikan pengaruh ketiga anteseden tersebut pada variabel job involvement, job satisfication, dan intrinsic motivation, serta OCB. Salah satu temuan Rich, et al. (2010) bahwa job engagement memediasi pengaruh value congruence dan core self-evaluations terhadap OCB di uji ulang dalam penelitian ini untuk melihat generalisasinya pada UKM Kerajinan di Kasongan, Bantul, Yogyakarta yang merupakan sedikit dari UKM yang berhasil mengekspor produknya menarik untuk dipelajari dari sudut pandang OCB atau usaha ekstra individu. Keselarasan nilai pekerja pembuat kerajinan dengan nilai UKM Kerajinan di Kasongan Bantul Yogyakarta dapat dipahami sebagai value congruence. Penilaian diri sendiri sebagai bagian dari evaluasi diri pada pekerja kerajinan di Kasongan Bantul juga ingin diuji apakah berdampak pada job engagement.

Value congruence

merupakan keselarasan antara nilai perusahaan dengan nilai pribadi pekerja. Ketika pekerja percaya bahwa nilai-nilai pribadi mereka sesuai dengan orang-orang dari organisasi di tempat bekerja, dan peran kerja mereka sesuai yang diharapkan organisasi, mereka akan menemukan lebih banyak kebermaknaan dalam pekerjaan, dan pada gilirannya mempunyai keterikatan dan keterlibatan diri yang lebih tinggi. Penelitian (May, Gilson, \& Harter, 2004) telah mendukung bahwa value congruence memudahkan individu berinvestasi lebih besar dengan mengejar tujuan organisasi karena mengalami makna peran kerja mereka. Value congruence dianggap nilai intrinsik motivasi diri (Ryan \& Deci, 2000). Secara khusus, hal 
tersebut mendorong job engagement dengan keterlibatan diri karyawan (kognitif, perilaku, dan emosional) ke pekerjaan yang mereka lakukan dan mengimplikasi dalam kinerja pekerjaan mereka (Kahn, 1990, 1992). Penelitian telah mendukung bahwa value congruence karyawan berdampak untuk mencapai tujuan organisasi melalui keterlibatan pekerjaan (Brown \& Leigh, 1996; May et al., 2004).

H1: Value congruence berpengaruh terhadap job engagement.

$$
\text { Core Self-Evaluation }
$$

merupakan konsep mengenai keseluruhan persepsi mendasar bahwa individu memiliki kemampuan untuk menilai diri mereka sendiri sebagai manusia (Judge, Locke, Durham, \& Kluger, 1998). Pekerja dengan kepribadian reflektif digambarkan sebagai kesiapan individu untuk secara pribadi terlibat pada saat tertentu (Kahn, 1990). Individu dengan kesediaan psikologis menganggap diri mereka siap melakukan peran kinerja serta cenderung menunjukkan keterlibatan yang lebih tinggi dalam konteks kinerja. Individu dengan evaluasi diri yang tinggi menilai tuntutan yang lebih positif, memiliki kemampuan yang lebih besar untuk mengatasi tuntutan pekerjaan, sehingga memiliki lebih banyak sumber daya yang tersedia untuk melakukan pekerjaan (Judge \& Hurst, 2007). Karena individu dengan evaluasi diri yang tinggi cenderung merasa lebih mampu menangani tuntutan pekerjaan, mereka juga bersedia untuk terlibat dalam pekerjaan. Dengan demikian, core self-evaluations berhubungan positif dengan keterlibatan pekerjaan (Erez \& Judge, 2001).

$\mathrm{H} 2$ : Core self-evaluations berpengaruh terhadap job engagement.

Job engagement adalah ekspresi kerja, kognitif, dan emosional dari anggota organisasi dalam melaksanakan peran mereka, tingkat alokasi sejauh mana karyawan menyesuaikan ego mereka dalam peran organisasi (Kahn, 1990; Saks, 2006). Menurut Schaufeli, Salanova, \& Gonza'lez-Roma (2002) job engagement adalah hal yang positif, dengan keterlibatan pekerjaan merupakan tanda dari semangat dan dedikasi dari karyawan. Individu yang mengalami keterlibatan cenderung merasa berharga, berguna, dan mampu untuk memberikan diri untuk peran pekerjaan mereka dan untuk orang lain (Kahn, 1990). Manajer menghargai OCB karena diyakini mampu menciptakan lingkungan kerja yang kondusif untuk bekerjasama dan berkontribusi pada kinerja organisasi. Ini membantu mengurangi jumlah waktu manajer menyelesaikan masalah dan memungkinkan fokus pada bidang lain untuk meningkatkan kinerja organisasi (Turnipseed \& Rassuli, 2005). Fay \& Sonnentag (2012) memperluas dan membangun teori dan penelitian terkait adanya hubungan positif bahwa job engagement mempengaruhi OCB. Pekerja yang memiliki keterikatan emosi terhadap perusahaan akan mengerjakan tugasnya tanpa merasa terbebani dibanding karyawan lain yang tidak memiliki keterikatan. Keterikatan dari pekerja diharapkan 
mampu menciptakan usaha ekstra pekerja bagi organisasinya.

H3: Job engagement berpengaruh terhadap OCB.

Kesesuaian nilai merupakan komponen motivasi yang melekat pada pribadi individu, nilai dapat menjadi kekuatan untuk mendorong dan membimbing individu mencapai prestasi yang diinginkan (Parks \& Guay, 2009). Kesesuaian nilai dalam organisasi diyakini dapat membuat individu didalam organisasi merasa nyaman untuk melaksanakan pekerjaan yang menjadi tanggung jawab individu, dan ketika mereka merasa memiliki peran kerja sesuai yang diharapkan organisasi, mereka akan menemukan lebih banyak kebermaknaan dalam pekerjaan, dan pada gilirannya mempunyai keterikatan dan keterlibatan diri yang lebih tinggi dan akan bekerja tidak hanya in-role namun juga extra-role di dalam organisasi mereka. Louis, Jeffrey, \& Eean (2010) menemukan pengaruh job enggagement terhadap kinerja karyawan.

$\mathrm{H} 4$ : Value congruence berpengaruh terhadap OCB.

Core self-evaluations merupakan analisis kepuasaan diri mereka sendiri terhadap pekerjaan yang dilakukan. Core self-evaluations terdiri dari empat komponen: harga diri, keefektifan diri umum, locus control, dan neurotisisme, harga diri adalah nilai keseluruhan pada dirinya sendiri, dan konsep ini berkaitan dengan kepuasan kerja (Judge et al., 1998), keefektifan diri merupakan persepsi seseorang tentang kemampuannya untuk menyelesaikan urgensi kehidupan, locus of control berkaitan dengan sejauh mana individu percaya bahwa mereka mengendalikan peristiwa dalam kehidupan mereka, sedangkan neurotisisme berhubungan negatif dengan kepuasan kerja (Griffin, 2001). Individu dengan evaluasi diri yang tinggi menilai pekerjaan yang mereka lakukan secara positif dan memiliki kemampuan yang lebih besar untuk menyelesaikan pekerjaan (Judge \& Hurst, 2007). Individu dengan evaluasi diri yang tinggi dapat menciptakan suasana OCB dalam diri mereka sebagai anggota organisasi.

H5: Core self-evaluations berpengaruh terhadap OCB.

Penelitian telah menemukan bahwa value congruence positif terkait dengan kinerja pekerjaan dan job engagement

(Kristof-Brown, Zimmerman, \& Johnson, 2005). Abraham (2012) menghubungkan keterlibatan pekerjaan mereka dengan komitmen organisasi dan niat mereka untuk tetap di organisasi. Penelitian lain menunjukkan peran supervisor dalam meningkatkan keterlibatan karyawan dan mencapai tingkat yang lebih tinggi pada komitmen organisasi dengan meningkatkan hubungan antara manajer dan rekan kerja yang mengarah pada keterlibatan kerja yang lebih baik sehingga meningkatkan komitmen organisasi (Harter, Schmidt dan Hayes, 2002). Job engagement dari emosional karyawan dapat menciptakan komitmen karyawan atas pekerjaannya dan kesediaan memberikan yang terbaik dalam mencapai tujuan organisasi.

H6: Job engagement memediasi pengaruh value congruence terhadap OCB. 
OCB didefinisikan sebagai perilaku yang berhubungan dengan pekerjaan di luar tugas rutin yang telah ditentukan atau diukur dalam evaluasi formal (Bateman \& Organ, 1983). Pekerja UKM Kerajinan Kasongan yang memiliki OCB akan bekerja tidak hanya in-role namun juga extra-role, artinya bahwa pekerja UKM tidak akan mendapat upah dari OCB, bentuk extra-role yang dilakukan misalnya dengan membantu pekerja lain pada sesi istirahat atau berangkat lebih pagi dan pulang lebih lama dari keharusan meski tidak ada perintah. Individu dengan evaluasi diri yang tinggi cenderung merasa lebih mampu menangani tuntutan pekerjaan, mereka juga harus bersedia untuk terikat dalam pekerjaan, yang akan mempengaruhi komitmen pada organisasi. Individu dengan OCB yang dipengaruhi job engagement, berarti menjalankan tugas ekstra tanpa keluhan, ketepatan waktu, relawan dan membantu orang lain, menggunakan waktu secara efisien, konservasi sumber daya, berbagi ide dan positif terkait organisasi (Turnipseed \& Rassuli, 2005).

H7: Job engagement memediasi pengaruh core self-evaluations terhadap OCB.

\section{METODE}

Populasi dalam penelitian ini adalah semua karyawan UKM Kerajinan di Kasongan Bantul Yogyakarta tanpa batasan bentuk bidang usaha dengan jumlah data anggota populasi secara akurat tidak diketahui. Mayoritas UKM bergerak di bidang gerabah namun bentuk usaha lain adalah di bidang kerajinan kayu, bunga kering, kertas, dan batu juga terobservasi, beberapa UKM juga melakukan diversivikasi usaha seperti melayani proses produksi seperti pembakaran gerabah, menjual bahan mentah, dan menyediakan galeri bagi UKM lain disekitarnya. Pengambilan sampel menggunakan purposive sampling hanya pada karyawan yang telah bekerja minimal 2 tahun yaitu sebanyak 107 responden dan bukan pemilik UKM. Meskipun pemilik seringkali juga merangkap sebagai pekerja karena keterbatasan sumber daya, namun sampel dibatasi hanya pada karyawan agar tidak terjadi bias munculnya value congruence, core selfevaluations, job engagement dan OCB karena status kepemilikan. Pengujian hipotesis 1 sampai 4 menggunakan uji $t$ pada regresi linier berganda, dan pengujian hipotesis 5 dan 6 menggunakan sobel test. Indikator variabel job engagement meliputi keterlibatan fisik, kognitif, dan afeksi dari Rich et al., (2010), indikator value conggruence diambil $\mathrm{O}^{\prime}$ Reilly \& Chatman (1986); Porter, Steers, Mowday, \& Boulian (1974). Indikator core self-analysis diambil dari Karatepe, Mine, dan Ilkay (2010), indikator OCB diambil dari Shim \& Rohrbaugh (2014) Data variabel dalam penelitian ini telah diuji dan memiliki nilai validitas dan reliabilitas yang baik dengan taraf signifikansi $5 \%$ dan Cronbach's Alpha $>0,60$.

\section{HASIL DAN PEMBAHASAN}

Karakteristik responden mengenai asal UKM menunjukkan bahwa sebanyak 15,6\% UKM berdiri kurang dari 5 tahun, 57,3\% 5 sampai dengan 10 tahun, dan 27,1\% diatas 10 
tahun, ini menunjukkan bahwa $84,4 \%$ UKM telah memiliki pengalaman yang cukup dalam usahanya. Pada tingkatan usaha terkategori UKM, ternyata sebanyak $66,3 \%$ telah memiliki merek sendiri, ini menunjukkan lebih dari separuh UKM memiliki kepercayaan diri untuk memberi nama atas hasil produksinya. Meskipun 46,5\% UKM menyatakan bahwa hasil produk telah diekspor, namun hanya 18\% UKM yang menyatakan mayoritas pembelinya adalah asing, atau sebanyak $82 \%$ UKM mayoritas pembelinya masih lokal. Model regresi telah memenuhi best liner unbiased estimated melalui uji grafik normalitas p-plot, kolmogorov smirnov test, tolerance-VIF, scatterplot dan glejser test (Tabel 1).

Tabel 2 model 1 menunjukkan nilai $t$ variabel value congruence terhadap job engagement memiliki nilai probabilitas $<0,05$ atau signifikan, demikian juga nilai $t$ variabel value congruence dan job engagement terhadap OCB. Hipotesis pertama yang menyatakan value congruence berpengaruh terhadap job engagement diterima. Oleh karena itu maka UKM Kerajinan Kasongan Bantul perlu meningkatkan implementasi value congruence yang mencakup kesesuaian nilai tempat kerja dengan nilai karyawan untuk meningkatkan keterlibatan kerja. Di dalam perusahaan berskala kecil seperti UKM, jumlah karyawan yang sedikit dan hubungan relatif akrab dan kekeluargaan akan memudahkan pemilik untuk menciptakan value conggruence. Value congruence individu berpengaruh karena merupakan investasi pribadi yang besar melalui keterlibatan pekerjaan mereka (Brown \& Leigh, 1996; May et al., 2004), oleh karenanya pemilik perlu menanamkan nilai budaya perusahaan mengenai apa yang dilarang untuk dilakukan atau apa yang dipercaya untuk dilakukan kepada karyawan.

Tabel 1. Asumsi Klasik

\begin{tabular}{|c|c|c|c|c|c|c|c|c|}
\hline & \multirow[b]{2}{*}{$\begin{array}{l}\text { Var. } \\
\text { bebas }\end{array}$} & \multirow[b]{2}{*}{$\begin{array}{l}\text { Var. } \\
\text { terikat }\end{array}$} & \multicolumn{2}{|c|}{ Multikolonieritas } & \multicolumn{2}{|c|}{ Glejser test } & \multicolumn{2}{|c|}{$\begin{array}{c}\text { Kolmogorov-Smirnov } \\
\text { test } \\
\end{array}$} \\
\hline & & & $\begin{array}{c}\text { Toleranc } \\
\mathrm{e}\end{array}$ & VIF & $\mathrm{t}$ & Sig. & $\begin{array}{l}\text { Kolmogorov } \\
\text {-Smirnov Z }\end{array}$ & $\begin{array}{l}\text { Asymp. } \\
\text { Sig. (2- } \\
\text { tailed) }\end{array}$ \\
\hline Model & $\mathrm{VC}$ & \multirow{2}{*}{ JE } & 790 & 1,267 &,- 392 & ,696 & \multirow{2}{*}{, 577} & \multirow{2}{*}{894} \\
\hline 1 & CSE & & ,790 & 1,267 & 1,477 & ,143 & & \\
\hline Model & $\mathrm{VC}$ & \multirow{3}{*}{ OCB } & 759 & 1,317 & 1,407 & , 162 & \multirow{3}{*}{1,282} & \multirow{3}{*}{,075 } \\
\hline \multirow[t]{2}{*}{2} & CSE & & 771 & 1,297 &,- 205 & ,838 & & \\
\hline & JE & & ,957 & 1,045 &,- 912 & ,364 & & \\
\hline
\end{tabular}

Hipotesis kedua yang menyatakan core self-evaluations berpengaruh terhadap job engagement ditolak. Statistik deskriptif dari indikator core self-evaluations dengan urutan rata-rata terbesar hingga terkecil adalah sebagai berikut: tekanan secara mental, keraguan terkait kompetensi, kegagalan yang membuat tidak berharga, putus asa dengan masalah pribadi, tidak dapat mengendalikan pekerjaan. Hasil core 

self-evaluations $\begin{gathered}\text { tersebut } \\ \text { keterlibatan }\end{gathered}$ tidak
menciptakan (2010). Individu dengan evaluasi diri yang tinggi menilai tuntutan secara positif, memiliki kemampuan yang lebih besar untuk mengatasi tuntutan pekerjaan, sehingga memiliki lebih banyak sumber daya yang tersedia untuk melakukan pekerjaan (Judge \& Hurst, 2007) ternyata tidak terbukti pengaruhnya pada penelitian ini.

Hipotesis

menyatakan job engagement berpengaruh terhadap organizational citizenship behavior diterima. Pemilik UKM Kerajinan dapat menggunakan statistik deskriptif indikator job engagement dengan rata-rata tiga terendah yang masih dapat diperbaiki: pikiran yang terfokus pada pekerjaan, berkonsentrasi pada pekerjaan, dan mengabdikan banyak energi untuk pekerjaan, dan secara luas pada peningkatan keterlibatan kognitif, afektif, dan fisik. Ketiga keterlibatan tersebut dalam kearifan lokal disebut dengan istilah ngerti (mewakili kognisi), ngroso (afeksi), dan nglakoni (fisik). Job engagement adalah ekspresi kerja, kognitif, dan emosional dari anggota organisasi dalam melaksanakan peran mereka, tingkat alokasi sejauh apa karyawan menyesuaikan ego mereka dalam peran organisasi (Saks, 2006). Bila indikator tersebut ditingkatkan maka OCB karyawan akan semakin meningkat. Hasil penelitian ini mendukung temuan terdahulu dari Fay dan Sonnentag (2012), keterlibatan berakar pada kondisi psikologis kebermaknaan, keamanan, dan ketersediaan, persepsi diri, dan konteks kerja (Kahn, 1990).

Hipotesis keempat yang menyatakan bahwa value congruence berpengaruh terhadap OCB diterima. Hal ini bermakna bahwa jika value conggruence meningkat maka organizational citizenship behavior juga akan meningkat. Oleh karena itu, UKM Kerajinan Kasongan Bantul perlu meningkatkan implementasi value congruence yang mencakup kesesuaian nilai pegawai dengan nilai tempat kerja untuk meningkatkan kinerja individu sehingga dapat meningkatkan efektivitas dan efisiensi organisasi. Value congruence dalam organisasi diyakini dapat membuat individu merasa nyaman untuk melaksanakan pekerjaan yang menjadi tanggung jawab individu, ketika karyawan merasa memiliki peran kerja sesuai yang diharapkan organisasi, mereka akan menemukan lebih banyak kebermaknaan dalam pekerjaan, dan pada gilirannya bekerja melebihi tanggungjawabnya (Louis et al., 2010). 


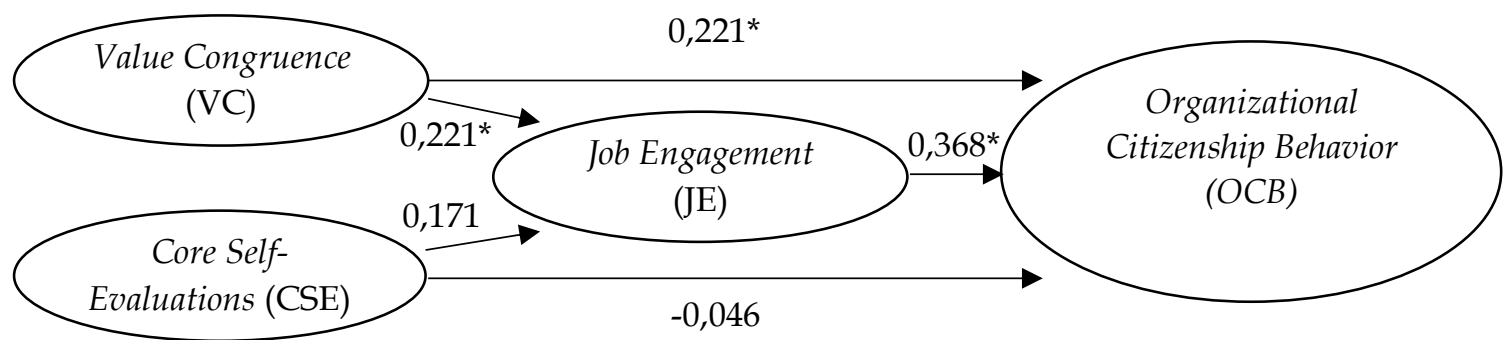

Keterangan:

$p \quad *<0,05$

Gambar 1 Model Penelitian

Hipotesis kelima yang menyatakan bahwa core self-evaluations berpengaruh terhadap OCB ditolak. Temuan tidak mendukung riset Judge \& Hurst, 2007, maupun Rich et al. 2010. Nampak bahwa persepsi dukungan organisasi terhadap karyawan (Rich et al. 2010) atau variabel lain perlu disertakan untuk melihat dampaknya terhadap OCB. Bila evaluasi diri karyawan bergerak ke arah positif karena kontrol dari persepsi dukungan organisasi melalui peningkatan motivasi internal dan eksternal seperti manajemen kompensasi oleh organisasi maka dimungkinkan akan menciptakan rasa memiliki dan empati terhadap organisasi yang berwujud pada OCB.

Pengujian hipotesis 6 dan 7 menggunakan uji Sobel test (Sobel, 1982).
$Z=a b / \sqrt{ }\left(\llbracket\left(b \rrbracket \wedge 2\right.\right.$ $\left.\llbracket S E \rrbracket a^{\wedge} 2\right)+\left(a^{\wedge} 2\right.$

$\left.\llbracket \mathrm{SE} \rrbracket\left[\mathrm{b}^{\wedge} 2\right)\right)$

Keterangan:

$a=$ koefisien regresi variabel

independe terhadap variabel

mediasi;

$b=$ koefisien regresi variabel mediasi terhadap variabel dependen;

$\mathrm{SEa}=$ standard error of estimation dari pengaruh variabel independen terhadap variabel mediasi;

$\mathrm{SEb}=$ standard error of estimation dari pengaruh variabel mediasi terhadap variabel dependen.

Model Mediasi I

$Z=(1,766.0,368) / \sqrt{ }(\llbracket(0,368 \rrbracket \wedge 2 . \rrbracket$

$0,864 \rrbracket \wedge 2)+(\llbracket 1,766 \rrbracket \wedge 2 . \llbracket 0,018 \rrbracket$

^2))

$Z=4,77510766$

Tabel 2. Regresi Linier Berganda

\begin{tabular}{|c|c|c|c|c|c|c|c|c|}
\hline \multirow[t]{2}{*}{ Model } & \multirow[t]{2}{*}{ Var. Bebas } & \multirow[t]{2}{*}{ Var. Terikat } & \multicolumn{2}{|c|}{$\begin{array}{l}\text { Unstandardized } \\
\text { Coefficients }\end{array}$} & \multirow{2}{*}{$\begin{array}{c}\begin{array}{c}\text { Standardized } \\
\text { Coefficients }\end{array} \\
\text { Beta }\end{array}$} & \multirow[t]{2}{*}{$t$} & \multirow[t]{2}{*}{ Sig. } & \multirow{2}{*}{$\begin{array}{l}\text { Adj. } \\
R \text { Sq. }\end{array}$} \\
\hline & & & $B$ & Beta & & & & \\
\hline \multirow{3}{*}{1} & (Constant) & & 107,00 & 21,789 & & 4,911 & , 000 & \\
\hline & $V C$ & $J E$ & 1,766 & ,864 & 221 & 2,044 & 044 & 025 \\
\hline & CSE & & ,475 & ,299 & ,171 & 1,587 & ,116 & \\
\hline \multirow{4}{*}{2} & (Constant) & \multirow{4}{*}{$O C B$} & & 4,432 & &,- 135 & ,893 & \multirow{4}{*}{,188 } \\
\hline & $V C$ & & 211 & ,162 & 211 & 2,105 & , 038 & \\
\hline & CSE & &,- 046 & ,055 &,- 046 &,- 460 & ,647 & \\
\hline & $J E$ & & ,368 & ,018 & ,368 & 4,118 & , 000 & \\
\hline
\end{tabular}


Hasil perhitungan sobel test nilai z 4,77510766>1,98 dengan tingkat signifikansi 5\% maka hipotesis ke 6 yang menyatakan bahwa Job engagement memediasi pengaruh value congruence terhadap OCB, diterima. Hasil pengujian menunjukkan variabel value congruence dapat mempengaruhi OCB baik secara langsung atau secara tidak langsung melalui Job engagement. Nilai kongruensi berpengaruh positif terhadap job engagement (KristofBrown, et al., 2005) dan job engagement berpengaruh terhadap niat karyawan untuk bertahan di perusahaan (Abraham, 2012). Peluang bagi UKM dengan sumber daya keuangan terbatas, karena satu strategi yaitu melakukan penyesuaian nilai karyawan dengan nilai perusahaan memiliki dua manfaat sekaligus: (1) menciptakan keterlibatan fisik, emosi, dan pikiran karyawan, (2) sekaligus menciptakan individu yang akan bekerja ekstra dan secara kumulatif meningkatkan efektifitas organisasi. Nilai-nilai organisasi dikomunikasikan kepada anggota organisasi dalam hal perilaku apa yang tepat dan diharapkan untuk peran pekerjaan mereka (Chatman, 1989; Ravlin \& Meglino, 1987), dan karena nilai-nilai pribadi mencerminkan, sebagian perilaku standar dan keinginan terlibat dalam citra diri seseorang (Cable \& Edwards, 2004), peran value congruence menjadi jelas.

Model Mediasi II

$\mathrm{Z}=(0,475.0,368) / \sqrt{ }(\rrbracket(0,368 \rrbracket \wedge 2$. 『 $0,299 \rrbracket \wedge 2)+(\llbracket 0,475 \rrbracket \wedge 2 . \llbracket 0,018 \rrbracket$

$\wedge 2)$ )

\section{$Z=1,28688161$}

Temuan sobel test menunjukkan nilai z 1,28688161<1,98 (5\%) maka hipotesis ke 7 yang menyatakan job engagement memediasi pengaruh core selfevaluations terhadap OCB, ditolak. Temuan ini tidak mendukung riset terdahulu dari Rich et al. (2010), evaluasi diri yang telah dilakukan karyawan tidak membentuk keterikatan dengan pekerjaannya meskipun temuan penelitian ini membuktikan keterikatan pekerjaan membentuk OCB. Core self-evalutions dapat menghasilkan pandangan negatif atau positif mengenai evaluasi dirinya, namun pengaruh pandangan negatif ataupun positif tidak ada pengaruhnya terhadap job engagement.

\section{KESIMPULAN}

Job engagement adalah variabel mediasi bagi pengaruh value conggruence terhadap OCB, meskipun begitu value conggruence juga dapat berpengaruh langsung terhadap OCB. Terdapat pengaruh job engagement terhadap $\mathrm{OCB}$, namun hasil penelitian gagal membuktikan pengaruh core self-evaluations terhadap OCB dimediasi oleh job engagement. Core self-evaluations juga tidak memiliki pengaruh signifikan terhadap OCB. Temuan riset ini perlu diperdalam dengan melihat variabel lain yang dapat mempengaruhi job engagement seperti karakteristik pekerjaan, kompensasi, umpan balik dan autonomi. Penyebab OCB juga perlu dikaji melalui faktor seperti persepsi dukungan organisasi dan faktor psikologis lainnya. Secara praktis temuan menyarankan UKM untuk 
selalu menanamkan nilai perusahaan kepada karyawannya agar terjadi kesesuian dengan nilai individu karyawan. Demikian juga keterlibatan kognitif (ngerti), afektif (ngroso), dan fisik (nglakoni) karyawan dalam berkarya di bidang kerajinan dan seni perlu dipertahankan karena telah mampu membawa reputasi UKM dengan mengekspor produknya.

\section{DAFTAR PUSTAKA}

Abraham D S 2012. Development of Employee Engagement Program on the Basis of Employee Satisfaction Survey. Journal of Economic Development, Management, IT, Finance and Marketing, 4 (1): 2737.

Bateman T S, Organ D W. 1983. Job satisfaction and the good soldier: The relationship between affect and employee citizenship. Academy of Management Journal, 26, 587595.

Brown S P dan Leigh T W. 1996. A new look at psychological climate and its relationship to job involvement, effort, and performance. Journal of Applied Psychology, 81: 358 -368.

Cable D M dan Edwards J. R. 2004. Complementary and supplementary fit: A theoretical and empirical integration. Journal of Applied Psychology, 89: 822- 834.

Chatman J A. 1989. Improving interactional organizational research: A model of person- organization fit. Academy of Management Review, 14: 333349.

Erez A dan Judge T A. 2001. Relationship of core self evaluations to goal setting, motivation, and performance. Journal of Applied Psychology, 86: 1270 - 1279.

Fay D dan Sonnentag S. 2012. Within -person fluctuations of proactive behavior: How affect and experienced competence regulate work behavior. Human Performance, 25(1), 72-93.

Griffin M A. 2001. Disposition and work reactions: A multilevel approach. Journal of Applied Psychology, 86, 1142-1151.

Harter J K, Schmidt F L, Hayes T L. 2002. Business unit-level relationship between employee satisfaction, employee engagement, and business outcomes: A metaanalysis. Journal of Applied Psychology, 87: 268 - 279.

Judge T A dan Hurst C. 2007. The benefits and possible costs of positive core self-evaluations: A review and agenda for future research. In D. L. Nelson \& C. L. Cooper (Eds.), Positive organizational behavior: 159 174. London: Sage.

Judge T A, Locke E A, Durham C C, dan Kluger A N. 1998. Dispositional effects on job and life satisfaction: The role of core evaluations. Journal of Applied Psychology, 83, 17-34. 
Kahn W A. 1990. Psychological conditions of personal engagement and disengagement at work. Academy of Management Journal, 33: 692-724.

Kahn W A. 1992. To be fully there: Psychological presence at work. Human Relations, 45: 321-349.

Karatepe O M, Mine H, Ilkay Y. 2010. The Impacts of Core SelfEvaluations on CustomerRelated Social Stressors and Emotional Exhaustion. The Service Industries Journal, 30, 1112.

Kristof-Brown A L, Zimmerman R. D, Johnson E C. 2005. Consequences of individual's fit at work: A meta-analysis of person-job, personorganization, Educational and Psychological Measurement, 64: 878-893.

Louis B, Lepine J A, Crawford E R. 2010. Job Engagement: Antecedents and Effects on Job Performance. Academny of Management Journal, Vol. 53, No. 3, 617-635.

May D R, Gilson R L, Harter L M. 2004. The psychological conditions of meaningfulness, safety and availability and the engagement of the human spirit at work. Journal of Occupational \& Organizational Psychology, 77: 11- 37.

O'Reilly C A, Chatman J A. 1986. Organizational commitment and psychological attachment:
The effects of compliance, identifi cation and internalization on prosocial behavior. Journal of Applied psychology, 71, 492- 499.

Parks L, Guay R P. 2009. Personality, values, and motivation. Personality and Individual Differences, 47, 675684

Porter L W, Steers R M, Mowday R T, Boulian P V. 1974. Organizational commitment, job satisfaction, and turnover among psychiatric technicians. Journal of Applied Psychology, 59(5), 603-609.

Ravlin E C, Meglino B M. 1987. Effect of values on perception and decision making: A study of alternative work values measures. Journal of Applied Psychology, 72: $666-673$.

Rich B L, Jeffrey A L, Eean R C. 2010. Job engagement: Antecedents and Effects on Job Performance. Academy of Management Journal. 53 (3): 617635.

Ryan R M, Deci E L. 2000. Selfdetermination theory and the facilitation of intrinsic motivation, social development, and well-being. American Psychologist, 55(1), 6878.

Saks A M. 2006. Antecedents and consequences of employee engagement. Journal of Managerial Psychology, 21: 600619. 
Schaufeli W B, Salanova M, Sobel M E. 1982. Asymptotic Gonza'lez-Roma' V, Bakker A. confidence intervals for indirect 2002. The measurement of effects in structural equation burnout and engagement: A confirmatory factor analytic approach. Journal of Happiness Studies, 3: 71-92.

Shim D C, Rohrbaugh J. 2014. An explanation of differences between government offices in employees' organizational citizenship behavior. Public Management Review, 16 (6): 807829. models. In S. Leinhardt (Ed.). Sociological Methodology 1982: 290-312.

Turnipseed D L, Rassuli A. 2005. Performance perceptions of organizational citizenship behaviors at work: abi-level study among managers and employees. British Journal of Management, 16, 231-244. 